\title{
Specific chemotherapy of Chagas disease: a comparison between the response in patients and experimental animals inoculated with the same strains
}

Sonia G. Andrade ${ }^{1}$, Anis Rassi ${ }^{2}$, Juracy B. Magalhaes ${ }^{1}$, Francisco Ferriolli Filho ${ }^{3}$ and Alexandro O. Luquetti ${ }^{2}$ ${ }^{1}$ Gonçalo Moniz Reserach Centre, Rua Valdemar Falcao 121 (Brotas), 41.945 Salvador, Bahia, Brazil; ${ }^{2}$ Federal University of Goiás School of Medicine, Goiania, Goiania, Brazil; ${ }^{3}$ Medical Faculty of Ribeirao Preto (USP), Ribeirao Preto, Sao Paulo, Brazil

\begin{abstract}
Eleven strains of Trypanosoma cruzi were isolated from patients with Chagas disease in central Brazil by xenodiagnosis and inoculation into newborn mice. Biological characterization and isoenzyme analysis showed that 6 strains were type II (zymodeme 2) and 5 were type III (zymodeme 1). Patients were treated with benznidazole or benznidazole plus nifurtimox. Mice infected with each isolated strain were treated for comparison with the results obtained in the respective patient. Evaluation of cure of the patients was based on the indirect immunofluorescence test, complement fixation reaction and xenodiagnosis. For the mice, haemoculture, indirect immunofluorescence testing, xenodiagnosis and inoculation of blood into newborn mice were used. Tests were performed 3-6 months after the end of treatment. The cure rate was $66-100 \%$ in mice infected with type II strains and $0-9 \%$ in those infected with type III strains. The correlation between treatment results in patients and mice was $81.8 \%$ ( 9 of 11 cases). Type II strains were more susceptible to treatment, in contrast to type III strains which yielded the majority of therapeutic failures.
\end{abstract}

\section{Introduction}

Treatment of patients with acute and chronic Chagas disease with the drugs in current clinical use (benznidazole and nifurtimox) has yielded disparate results (BOAINAIN \& RASSI, 1979; PRATA et al., 1975). Discrepancies are even greater when therapeutic trials from different geographical areas are compared. CERISOLA et al. (1974) in Argentina claimed an $81 \%$ cure rate with nifurtimox in acute infections. In Brazil the reported rates with the same drug were $38.4 \%$ (RASSI \& FERREIRA, 1971) and $33.3 \%$ (CANÇADO, 1985). With benznidazole, LEDESMA pared, in the hope that this would help to clarify the role of parasite strain in susceptibility and resistance to drug treatment.

\section{Materials and Methods}

The area in central Brazil from which the 11 strains of $T$. cruzi were isolated has been described by LUQUETTI $e t$ al. (1986). Six cases were from Montalvania, north-west Minas Gerais state, 4 came from Carinhanha, Bahia and one from A. Dourados, close to the eastern border of Goias state.

Table. Correlation between the clinical and experimental response to chemotherapy of Chagas disease with benznidazole and nifurtimox

\begin{tabular}{|c|c|c|c|c|c|c|c|c|c|c|c|}
\hline \multirow{2}{*}{$\begin{array}{l}\text { Case } \\
\text { no. }\end{array}$} & \multicolumn{2}{|c|}{ Clinical data ${ }^{a}$} & \multirow{2}{*}{$\begin{array}{l}\text { Clinical } \\
\text { form }\end{array}$} & \multicolumn{3}{|c|}{ Clinical chemotherapy $^{\mathrm{b}}$} & \multicolumn{3}{|c|}{$\begin{array}{l}\text { Experimental data } \\
\text { Strain characterization }\end{array}$} & \multicolumn{2}{|c|}{$\begin{array}{l}\text { Experimental } \\
\text { chemotherapy } \\
\text { Cure rate }(\%)\end{array}$} \\
\hline & (years) & Sex & & $(\mathrm{mg} / \mathrm{kg})$ & Duration (d) & results & Identity & Type & Zymodeme & Benznidazole & Nifurtimox \\
\hline 1 & 13 & Female & Acute & 10 & 60 & Resistant & 1-MONT & III & $Z_{1}$ & $9 \cdot 0$ & $5 \cdot 8$ \\
\hline 2 & 42 & Male & Chronic & 8 & 60 & Resistant & 4-MONT & II & $\overline{\mathrm{Z}}_{2}$ & 0 & 0 \\
\hline 3 & 40 & Male & Acute & 5 & 60 & Resistant & 8-MONT & III & $\mathrm{Z}_{1}$ & 0 & 0 \\
\hline 4 & 35 & Female & Acute & 6 & 60 & Cured & Y-MONT & III & $Z_{1}$ & 0 & 0 \\
\hline 5 & 5 & Female & Acute & 10 & 60 & Cured & 12-MONT & II & $\mathrm{Z}_{2}$ & 100 & 100 \\
\hline 6 & 13 & Female & Acute & 10 & 60 & Cured & 15-MONT & II & $Z_{2}$ & 66 & 100 \\
\hline 7 & 12 & Male & Acute & 10 & 60 & Cured & 20-MONT & II & $\mathrm{Z}_{2}$ & 100 & 100 \\
\hline 8 & 32 & Male & Acute & 5 & 60 & Cured & 22-MONT & II & $\mathrm{Z}_{2}$ & 100 & 100 \\
\hline 9 & 6 & Female & Chronic & 6 & 60 & Cured & 24-MONT & II & $\mathrm{Z}_{2}$ & 81 & 100 \\
\hline 10 & 11 & Female & Acute & 9 & 60 & Cured & 25-MONT & III & $Z_{1}$ & 0 & 0 \\
\hline 11 & 13 & Female & Acute & 6 & 60 & Resistant & 1-CAR & III & $Z_{1}$ & 0 & 0 \\
\hline
\end{tabular}

${ }^{8}$ Cases $1,5,6,7,8,10$ from Montalvania (MG); cases 3, 4, 9, 11 from Carinhanha (BA); case 2 from A. Dourados (MG).

bAll patients treated with benznidazole; cases 2 and 3 also trcated with nifurtimox. Case 2 : first treatment with nifurtimox, $8 \mathrm{mg} / \mathrm{kg}$ body weight $/ \mathrm{d}$ for $60 \mathrm{~d}$, not cured. Case 3: Second treatment with nifurtimox, $8.7 \mathrm{mg} / \mathrm{kg}$ body weight $/ \mathrm{d}$ for $75 \mathrm{~d}$, result inconclusive (serological reactions with variable results and negative xenodiagnosis).

'Strain 4-MONT isolated from previously treated patient (case 2).

(1988) obtained $80 \%$ cure in Argentina, while in Brazil the rates were $53.8 \%$ (CANÇ.ADO, 1985) and $51.3 \%$ (RASSI, 1982).

One of the factors contributing to these different results could be the parasite strain together with the predominance of certain stable strains in some geographical areas. Experimentally, there is evidence that parasite strain is an important factor influencing the results obtained with benznidazole and nifurtimox. Differences in susceptibility to these drugs correlate well with the biological characteristics of parasite strains (ANDRADE et al, 1985).

The present investigation was an attempt to compare clinical and experimental observations. Several strains of Trypanosoma cruzi were isolated from patients living in central Brazil and were characterized to strain types according to established criteria (ANDRADE, 1985; WHO, 1986). Results of treatment in the patient and in mice infected with the corresponding $T$. cruzi strain were com-
Description of clinical cases. General clinical data are given in the Table. Nine patients had acute Chagas disease ( 6 females and 3 males) and 2 had chronic infections (indeterminate form). Parasites were detected by direct examination of peripheral blood in all acute cases and by xenodiagnosis in the chronic cases.

Clinical chemotherapy. Nine patients were treated solely with benznidazole. Two other patients received nifurtimox either preceding (case 2) or following (case 3) treatment with benznidazole. Benznidazole ( $N$-benzyl-2(2 nitro-imidazol-1-yl)acetamide) was given orally in doses of $5-10 \mathrm{mg} / \mathrm{kg}$ body weight $/ \mathrm{d}$ divided into 2 or 3 doses, for $60 \mathrm{~d}$. Nifurtimox (tetrahydro-3-methyl-4-(nitrofurfuryldieneamino- 1,4 thiazine-1,1-dioxide) was given orally in doses of $8-8.7 \mathrm{mg} / \mathrm{kg}$ body weight $/ \mathrm{d}$ for 60 or 75 d (see Table).

Criteria of cure. Evaluation of therapeutic results was based on xenodiagnosis, indirect immunofluorescence (IIFT) and complement fixation reactions (CFR). Pa- 
tients were considered cured when both serological tests remained persistently negative and xenodiagnosis, performed monthly and repeated 25 or more times, was consistently negative. Xenodiagnosis was performed with 40 third-stage nymphs of Triatominae, which were examined 30 and $60 \mathrm{~d}$ after blood feeding.

Experimental procedures. T. cruzi was isolated from reduviid nymphs which had been used for xenodiagnosis and the strains were characterized by morpho-biological features (ANDRADE, 1985) and isoenzyme electrophoretic patterns (MILES, 1980; ANDRADE et al., 1983). Briefly, morpho-biological characterization consisted of the observation of parasitaemia curves, morphology of blood forms of the parasite, virulence, tissue tropism, and histopathology during experimental infections of mice. Isoenzyme patterns were determined from extracts of parasites cultured in Warren's medium. The following enzymes were studied: aspartate aminotransferase (E.C.2.6.1.1, ASAT), alanine aminotransferase (E.C.2.6.1.2., ALAT), phosphoglucomutase (E.C.2.7.5.1., PGM) and glucose phosphate isomerase (E.C.5.3.1.9., GPI).

Experimental chemotherapy. Each isolated strain was inoculated to a group of 70 mice each weighing $10-12 \mathrm{~g}$. Each mouse received $1 \times 10^{5}$ blood forms. Thirty mice were treated with benznidazole, 30 with nifurtimox, and 10 were left as untreated controls. Dosage schedules for the mice were based upon that used by HABERKORN \& GONNERT (1972), who established the equivalence between doses of 15 or $10 \mathrm{mg} / \mathrm{kg}$ body weight for adult men and doses of 180 or $120 \mathrm{mg} / \mathrm{kg}$ body weight for mice. An initial daily dose of $200 \mathrm{mg} / \mathrm{kg}$ of nifurtimox was given for $4 \mathrm{~d}$, followed by $50 \mathrm{mg} / \mathrm{kg}$ for $90 \mathrm{~d}$. Benznidazole was given on $5 \mathrm{~d}$ per week, at $100 \mathrm{mg} / \mathrm{kg}$ body weight, for $90 \mathrm{~d}$, according to RICHLE \& RAAFLAUB (1980).

Criteria of cure. Xenodiagnosis with 5 th stage $R$. prolixus nymphs, subinoculation of blood into newborn mice $(0.1 \mathrm{ml}$, intraperitoneally) and haemoculture were performed 3-6 months after treatment. The same tests were made on the control mice. IIFT was performed with $T$, cruzi culture forms as antigen and anti-mouse fluorescein-conjugated $\gamma$-globulin (dilution 1:80). Titres $>1: 10$ were considered to be positive.

\section{Results}

\section{Experimental results}

Six of the isolated $T$. cruzi strains belonged to type II (zymodeme 2) and 5 to type III (zymodeme 1) (Table). Mice infected with most type II strains had a cure rate of $66-100 \%$ when treated with benznidazole and nifurtimox (Table). One strain (4-MONT), from a previously treated patient, was an exceptional therapeutic failure. Responses of the type III strains to treatment were poor with both drugs, the cure rate being nil for 4 strains and only $5-9 \%$ for the other strains (1-MONT) (Table).

Assessment of cure was based on the parasitological tests, because the IIFT remained positive with all animals.

\section{Clinical results}

Seven of the 11 patients treated with benznidazole were considered cured, with both xenodiagnosis and serological tests consistently negative. Therapeutic failures were observed in 4 patients, 2 of whom were treated with both drugs (Table).

\section{Comparison of clinical and experimental results}

The results of clinical and experimental chemotherapy were in agreement in 9 of the 11 cases $(82 \%)$. Five of the 6 patients harbouring type II strains were cured, and mice infected with type II strains had a high cure rate.

\footnotetext{
"Four species were used, according to availability: Rhodnius prolixus, Triatoma brasiliensis, $T$. infestans and Dipetalogaster maxima.
}

Therapeutic failures were observed in 3 of 5 patients infected with type III strains $(60 \%)$, and mice infected with type III strains exhibited poor therapeutic responses.

\section{Discussion}

Morpho-biological classification into strain types as proposed by ANDRADE (1985) and zymodeme classification according to MILES et al. (1980) were in good agreement. Human infections with parasites belonging to both zymodemes 1 and 2 have already been reported in central Brazil by LUQUETTI et al. (1986).

Although the number of human cases in our series was rather small to permit definitive conclusions, the extent of agreement of therapeutic results in humans and mice was impressive. Previous experiments in mice have already demonstrated that type II strains of $T$. cruzi are more susceptible to drugs than type III strains, which are usually quite resistant (ANDRADE et al., 1985). Previous treatment is known to increase the resistance of a strain, and this may explain the exceptional resistance of the type II strain infecting case 2, the sole instance in this study of the parasites being isolated after the patient was treated. The 2 other instances of disagrcement between clinical and experimental results are more difficult to explain. Patients no. 4 and no. 10 were cured, but the isolated strains (type III, zymodeme 1) exhibited resistance to both nifurtimox and benznidazole in experimental infections.

The persistence of positive serological test in parasitologically cured mice is not surprising. It has been observed before and is correlated with the prolonged storage of $T$. cruzi antigens in dendritic spleen cells (ANDRADE et al., 1991).

The comparative therapeutic results in the 2 different host species strongly suggest that parasite strain is a key factor influencing chemotherapeutic outcome. Therefore, it is important to characterize a significant number of strains in a given geographical area and to test their susceptibility to anti-T. cruzi compounds, in order to increase the chance of successful treatment.

\section{Acknowledgements}

This work was supported by the UNDP/World Bank/WHO Special Programme for Research and Training in Tropical Diseases (S. G. Andrade) and the Brazilian Council for Scientific and Technological Development (CNPq) (S.G.Andrade).

Thanks are due to Dr José Florisval de Ornelas, Montalvania, Minas Gerais, for providing facilities for field work.

\section{References}

Andrade, S. G. (1985). Morphological and behavioural characterization of Trypanosoma cruzi strains. Revista da Sociedade Brasileira de Medicina Tropical, 18, supplement, 39-46.

Andrade, S. G., Magalhaes, J. B. \& Pontes, A. L. (1985). Evaluation of chemotherapy with benznidazole and nifurtimox in mice infected with Trypanosoma crusi of different types. Bulletin of the World Health Organization, 63, 721-726.

Andrade, V., Brodskyn, C. \& Andrade, S. G. (1983). Correlation between isoenzyme patterns and biological hehaviour of different strains of Trypanosoma cruzi. Transactions of the Royal Society of Tropical Medicine and Hygiene, 77, 796-799.

Andrade, S. G. Freitas, L. A. R., Peyrol, S., Pimentel, A. S. \& Sadigursky, M. (1991). Experimental chemotherapy of Trypanosoma cruzi infection. Persistence of parasite antigens and positive serology in parasitologically cured mice. Bulletin of the World Health Organization, 69, 191-197.

Boainain, E. \& Rassi, A. (1979). Terapeutica etiologica da doença de Chagas. Arquivos Brasileiros de Cardiologia, 32, 395-399.

Cançado, J. R. (1985). Tratamento especifico. In: Cardiopatia Chagasica, Cancado, J. R. \& Chuster, M. (editors). Belo Horizonte: Fundaçao Carlos Chagas, pp. 227-355.

Cerisola, J. A., Rohwedder, R., Segura, E. L., Del Prado, C. E., Alvarez, M. \& Martini, G. J. W. (1974). El Xenodiagnostico. Normatizacion. Utilidad. Buenos Aires: Imprenta del Instituto Nacional de Investigaciones Cardiovasculares.

Haberkorn, A. \& Gonnert, R. (1972). Animal experimental investigation into activity of nifurtimox against Trypanosoma cruzi. Arzneimittel-Forschung (Drug Research), 22, 1570-1582.

Ledesma, O. (1988). Tratamiento de la infeccion chagasica 
aguda. Revista de la Federacion Argentina de Cardiologia, 17, 232-233.

Luquetti, A. O., Miles, M. A., Rassi, A., Rezende, J. M., De Souza, A. A., Povoa, M. M. \& Rodrigues, I. (1986). Trypanosoma cruzi: zymodemes associated with acute and chronic Chagas disease in central Brazil. Transactions of the Royal Society of Tropical Medicine and Hygiene, 80, 462-470.

Miles, M. A., Lanham, S. M., Souza, A. A. \& Povoa, M

(1980). Further enzymic characters of Trypanosoma cruzi and their evaluation for strain identification. Transactions of the Royal Society of Tropical Medicine and Hygiene, 74, 221-237.

Prata, A., Macedo, V., Porto, G., Santos, I., Cerisola, J. A. \&

Silva, N. (1975). Tratamento da doença de Chagas pelo nifurtimox (Bay-2502). Revista da Sociedade Brasileira de Medicina Tropical, 9, 297-304.

Rassi, A. (1982). Tratamento etiologico da doença de Chagas. Arquivos Brasileiros de Cardiologia, 38, 277-281.
Rassi, A. \& Ferreira, H. O. (1971). Tentativas de tratamento especifico da fase aguda da doença de Chagas con nitrofuranos em esquemas de duracao prolongada. Revista da Sociedade Brasileira de Medicina Tropical, 5, 235-262.

Richle, R. W. \& Raaflaub, J. (1980). Difference of effective anti-trypanosomal dosages of benznidazole in mice and man. Chemotherapeutic and pharmacokinetic results. Acta Tropica, $37,257-261$.

WHO (1986). Report of the WHO Steering Committee. Research activities of the scientific working group on Chagas disease. Memorias do Instituto Oswaldo Cruz, 81, supplement, 181-224.

Received 14 Fanuary 1992; revised 24 March 1992, accepted for publication 24 March 1992

\section{Announcement}

\section{President's Fund}

Council has decided to launch an appeal to raise money with the aim of establishing a fund to sponsor prospective Fellows from developing countries, who are at present unable to become Fellows of the Society because of their country's fiscal rules which prevent them from paying.

The fund will be known as The President's Fund for Overseas Fellows in Developing Countries and will be used to sponsor deserving candidates for full Fellowship of the Society for a trial period of three years.

The Society will make an initial donation of $£ 2000$ from its reserves to launch the Fund, and will then rely on donations from Fellows (including Honorary and Life Fellows) of the Society, and other, perhaps commercial, sources to build up the fund.

Any Fellows willing to donate to the President's Fund in order to help sponsor a Fellow from a developing country, are asked to write to Manson House. 